\title{
ANALYSIS OF PRIVATE NATURAL HERITAGE RESERVES AS A CONSERVATION STRATEGY FOR THE BIODIVERSITY OF THE COCOA REGION OF THE SOUTHERN STATE OF BAHIA, BRAZIL ${ }^{1}$
}

\begin{abstract}
Alexandre Schiavetti ${ }^{2}$, Haydee Torres de Oliveira ${ }^{3}$,Alene da Silva Lins ${ }^{4}$ e Pablo Santana Santos ${ }^{5}$
ABSTRACT - Brazil was the first country in Latin America to establish and regulate this type of reserve, and there are currently more than 700 Private Nature Heritage Reserves (RPPN in Portuguese) officially recognized by either federal or state environmental agencies. Together, these RPPN protect more than a half million hectares of land in the country. The coastal forests in the southern part of Bahia State extend 100 to $200 \mathrm{~km}$ inland, gradually changing in physiognomy as they occupy the dryer inland areas. The coastal forest has been subjected to intense deforestation, and currently occupies less than $10 \%$ of its original area. For this work the creation processes of the RPPN were consulted to obtain the data creation time, size of property, the condition of the remaining forest, succession chain and the last paid tax. After that, interviews with the owners were made to confirm this data. Sixteen RPPN have been established in this region until 2005. Their sizes vary from 4.7 to 800 ha. Ten of these RPPN are located within state or federal conservation areas or their buffer zones. In spite of the numerous national and international conservation strategies and environmental policies focused on the region, the present situation of the cocoa zone is threatening the conservation of the region's natural resources. The establishment of private reserves in the cocoa region could conceivably improve these conservation efforts. This type of reserve can be established under a uniform system supported by federal legislation, and could count on private organizations.
\end{abstract}

Key words: Atlantic Coastal Forest, biodiversity conservation, private reserves and southern Bahia;

\section{ANÁLISE DAS RESERVAS PARTICULARES DO PATRIMÔNIO NATURAL COMO ESTRATÉGIA DE CONSERVAÇÃO NA REGIÃO CACAUEIRA DO SUL DA BAHIA, BRASIL}

\begin{abstract}
RESUMO - O Brasil foi o primeiro País na América Latina a estabelecer e regulamentar este tipo de reserva e hoje, há mais de 700 Reservas Particulares do Patrimônio Natural (RPPN) oficialmente reconhecidas pelos órgãos ambientais federais ou estaduais. Juntos, estas reservas protegem mais de meio milhão de hectares em diferentes biomas dos Pais. A Floresta Atlântica na região Sul da Bahia se estende até 200 km para o interior, gradualmente mudando sua fitofisionomia até as áreas mais secas. Esta formação florística vem sendo desmatada desde sua colonização e atualmente ocupa menos de 10\% de sua área original. Para este trabalho os processos no IBAMA para a criação das RPPN foram consultados para a obtenção dos dados de tempo de criação, tamanho da propriedade, estado de conservação do remanescente florestal, cadeia sucessória e ultimo imposto pago. Após essa sistematização, entrevistas com os proprietários foram realizadas para a confirmação dos dados. Dezesseis RPPN foram estabelecidas nesta região, com áreas variando entre 4,7 a 800 hectares, dentro de propriedades que variam de 14 a 1200 hectares. Dez destas RPPN estão localizadas dentro ou na zona de amortecimento de Unidades de Conservação federais ou estaduais. Apesar das inúmeras estratégias de conservação internacionais e das políticas ambientais nacionais focadas na região a situação da região cacaueira do Sul da Bahia é de forte ameaça de seus recursos naturais. O estabelecimento de reservas privadas nesta região pode aumentar o sucesso dos esforços de conservação, pois este tipo de reserva pode ser implantada em parceria entre o governo e as organizações privadas.
\end{abstract}

Palavras-chave: Floresta Atlântica, Conservação da biodiversidade, Reservas Privadas e Sul da Bahia;

\footnotetext{
${ }^{1}$ Recebido em 15.05.2008 e aceito para publicação em 02.03.2010.

${ }^{2}$ Universidade Estadual de Santa Cruz, UESC, Brasil. E-mail: <aleschi@uesc.br>.

${ }^{3}$ Universidade Federal de São Carlos, UFSCAR, Brasil. E-mail: <haydee@ufscar.br>.

${ }^{4}$ Universidade Federal do Recôncavo da Bahia, UFRB, Brasil. E-mail: <aleneufrb@gmail.com >.

${ }^{5}$ Universidade Federal da Bahia, UFBA, Brasil. E-mail: <pablosantos@ufba.br>.
} 


\section{INTRODUCTION}

\subsection{Protected Areas (PA) in Brazil and their Buffer Zones}

The creation of PA in Brazil was normalized in 2000 by Federal Law $n^{\circ} 9,985 / 2000$ that established the National System of Conservation Areas - SNUC, as later regulated by Federal Decree $n^{\circ} 4,340$, in 2002. This law created two complementary classes of PA in Brazil - the Full Protection Areas (that only allow indirect use of the component natural resources), and the Sustainable Use Areas (that allow direct use of the component natural resources). Together, there are a total of 12 different categories of PA that can be established in Brazil; 5 Full Protection, and 7 Sustainable Use Area categories (SILVA, 2005).

Associated with the Full Protection Areas are buffer zones. These are areas external to the PA (usually including private holding) in which the uses of the component natural resources are regulated due to their proximity to the CA. These buffer zones are designed to be established and administered not only with the object of minimizing environmental impacts to the reserve, but also to evaluated the economic impact on local human populations, and should include or recruit these residents into overall management of the PAitself (WELLS and BRANDON, 1993).

The creation of buffer zones is based on Resolution $n^{\circ}$ 013/1990 of the National Council of the Environment (CONAMA in Portuguese) that established a nominal $10 \mathrm{~km}$ buffer zone around all PA. With the passing of the National System of Conservation Areas law (SNUC, in Portuguese) in 2002, the width of the buffer zone became variable, based on the threatened status of each area. One of the advantages of this new regulation is the possibility of utilizing new functional approaches in establishing buffer zones, such as a watershed criterion. In spite of their theoretical importance to the establishment and implantation of PA, buffer zone functioning is often stymied by the fact that a majority of the agencies managing PA do not have the effective legal authority to establish and administer theses zones (WELLS and BRANDON, 1993).

According to Li et al (1999) buffer zones should be established not only on firm conservation strategies, but must also consider the local human populations. These authors proposed a method for establishing buffer zone for the Yancheng Biosphere Reserve in
China that would take into consideration current uses of the area by resident populations, tourism-use values, the environmental quality sought, as well as physical access to the reserve.

Mesquita et al (2000) pointed out that the creation of private reserves could be a powerful tool for the consolidation of buffer zones, because private reserves often cite public visitation as one of their goals. This visitation could generate an alternative source of income for local populations and thus relieve pressure on the native vegetation and/or replace other non selfsustaining activities.

\subsection{The creation of Private Reserves in Brazil}

Private reserves are considered a complementary strategy to public efforts to establish protected natural spaces. Many authors have pointed out the importance of establishing private reserves around protected areas (especially around Full Protection Areas) to mitigate external impacts (ALDERMAN, 1994, MESQUITA, 1999, LANGHOLZ, 2002).

Brazil was the pioneer nation in Latin America in creating private reserves, as the Forest Code of 1934 provided for the establishment of private protected areas, called "Forest Protectors". These areas remained private property, and where considered legally untouchable. With the reform of the Forest Code in 1965, the "Forest Protectors" category was eliminated, but the new law retained the option of declaring any portion of private land as a perpetual conservation area (Art. $6^{\circ}$, Federal Law no 4 771/1965). This required signing an agreement with the authorities and including that fact in the land deed. This new option, however, only became truly operational 25 years later with the official approval of this decree and the creation of the modern concept of private natural heritage reserves -(RPPN in Portuguese) (MESQUITA and VIEIRA, 2004).

Article 17 of the 1934 Forest Act established that forests were immune to taxation and as such did not increase the tax values of private lands. This same Article stated "protective forests are exempt from any taxation, including land taxes”.

With the introduction of The Forest Act of September 15, 1965 ( $n^{\circ} 4$ 771/65), significant changes were made to earlier laws. This new Forest Act extinguished the earlier classification system for forests, and the only legal creation mode in private lands was 
cited in its Article 6 ${ }^{\circ}$ : "The owners of forests that are not preserved, in the terms of this law, can declare them permanent preservation areas if the forest service decides that it is in the public interest to do so. Said agreement must be signed publicly and registered together with the deed to the property". Nonetheless, this article was never fully empowered (until 1990), and remained in an "inert" condition within the Forest Act.

In 1977 the (now extinct) Brazilian Institute for Forestry Development - IBDF published a guideline forestry ( ${ }^{\circ}$ 327) that instituted Natural Wildlife Refuges. This guideline was published in response to numerous calls from rural landowners in Rio Grande do Sul (the southern-most state in Brazil) who wished to restrain hunting on their properties.

Based on this guideline, the owners of rural areas could have their lands declared Natural Wildlife Refuges - although without receiving any direct economic incentive in adopting this form of conservation.

This idea was later extended to protect native vegetation (with the substitution of guideline $n^{\circ} 327 /$ 77-P for guideline IBDF-P n ${ }^{\circ} 217$ of July 1978), creating the concept of "Private Flora and Fauna Reserves".

By formulating these guidelines, the authorities were attempting to follow the dictates of the new 1998 Federal Constitution that commanded both the government and the public sector to defend the environment - which had been declared a resource of common good for everyone (Article 225).

In 1990, Federal Decree $n^{\circ} 98914$ created the institution of Private Natural Heritage Reserves (RPPN), which finally set the stage for the regulation of Article $6^{\circ}$ of the Forest Code, and in 1996 the first regulations were finally published (Decree $\mathrm{n}^{\circ} 1992$ ).

The basic idea of Decree $n^{\circ} 98$ 914/1990 was to broaden (the almost extinct) concept of Private Flora and Fauna Reserves, giving them a definitive list of regulations, a guarantee of perpetuity, incentives for creation by exempting them from taxes, and priority for environmental funding, as well as creating a network of private reserves in Brazil where citizens could voluntarily help to protect representative areas of the numerous Brazilian ecosystems.

This formulation allowed landowners to declare their lands RPPN but still retain full ownership, while taking advantage of the offer of full and perennial federal protection of these areas by the Brazilian Institute of the Environment and Renewable Natural Resources - IBAMA. As Sustainable - Use Conservation Areas (under law $n^{\circ} 9$ 985) only indirect uses of the areas are permitted: environmental education, scientific research, and ecological tourism.

This mechanism is based exclusively on the voluntary adhesion of the landowner to the concept of perpetually protecting his/her lands. There are no coercive mechanisms involved.

When a rural landowner requests for the creation of a RPPN on part of his property, a representative of the IBAMA is designated to visit the area and verify its appropriateness for the inclusion in the program. These areas are evaluated using guidelines set down by IBAMA (Decree ${ }^{\circ} 1922$ of June 5, 1996) that include an on-site visit to provide a description of the area, its vegetation, hydrology, and other natural attributes, as well as its state of conservation. All areas must be in a natural primitive state, or a recuperation phase, or have characteristics that justify recovery efforts.

A RPPN, once created, is perpetually legally binding. By law, the natural characteristics of the area cannot be altered in any way, nor can its designation as a conservation area be modified (IBAMA, 1997). The creation of a RPPN implies exemption from land taxes and, additionally, the owner can submit projects to finance the maintenance of the reserve to the National Fund for the Environment - FNMA (which was established to fund conservation projects in all of Brazil). The owners also gain priority in seeking agricultural credits through official institutions. Another advantage of this process is that it confers a social function on the land by preserving its natural value, and thus these areas cannot be appropriated for land-reform projects (IBAMA, 1997).

There are currently 720 RPPN officially recognized by the IBAMA or by state authorities (MESQUITA and VIEIRA, 2004). All together, these reserves protect more than 520000 hectares within the various biomes in Brazil. While this number may seem small in comparison to the more than 540 million hectares included within public protection areas, the importance of these protected private lands must be highly stressed in light of the fact that these farmers, institutions, and companies could otherwise be using these areas for agriculture or cattle ranching (MESQUITA and VIEIRA, 2004).

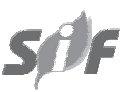

Revista Árvore, Viçosa-MG, v.34, n.4, p.699-711, 2010 


\subsection{The Atlantic Coastal Forest and the importance of its conservation}

The Atlantic Coastal Forest originally covered essentially the entire Brazilian Atlantic coast (1 227 $600 \mathrm{~km}^{2}$ ), from the state of Rio Grande do Norte (in the extreme northeastern part of the country), all the way to Rio Grande do Sul (in the extreme south). However, this once extensive forest has now been reduced to a mere $91930 \mathrm{~km}^{2}$ due to heavily used by human populations even before colonization by Europeans in the early $16^{\text {th }}$ century (DA FONSECA, 1985). Hannah et al (1994) classified the largest ecosystems of our planet according to their degree of disturbance, and cited the Atlantic Coastal Forest as the second most altered Neotropical continental ecosystem.

After colonization, different economic cycles and different manners of exploiting the natural resources of this area followed one another closely - including the extensive planting of sugarcane or coffee in the northern and southern areas of this biome, respectively. The reduction of approximately $92,5 \%$ of its former cover represents an incalculable loss of scientific information, as a large part of this biome was never closely examined before being cleared.

According to Mittermeier et al (1998), the Atlantic Coastal Forest is one of the world's biodiversity "hotspots", and is considered one of the five most important systems ("hottest hotspots") to be conserved, principally due to its high degree of endemism and its already greatly reduced area.

Brazilian legislation (Federal Decree $n^{\circ} 750 / 1993$ ) established the legal limits of the Atlantic Coastal Forest and defined the prerequisites that must be respected in order to apply for logging permits or rational use in that biome. Only 36\% of the remaining area of the Atlantic Forest is under any sort of legal protection regime within the different categories of PA under Brazilian law. According to Myers et al (2000) the total area included within these various PA is 33084 ha. Capobianco (2001) lists 187 PA within the federal sphere, and approximately 520 PA at the state level within the Atlantic Coastal Forest biome.

The coastal forest in southern Bahia (an area of approximately $14000 \mathrm{~km}^{2}$ ) extends inland between 100 and $200 \mathrm{~km}$ along the entire coastline, gradually changing its physiognomy as it moves inland. Along the coast, the physiognomy is that of a rain forest, gradually transitioning into a semi-deciduous moist forest and then a dry deciduous forest more towards the west. This physiognomic transition is due to gradually diminishing rainfall as well as changes in the soils and the topography (see THOMAS et al., 1998).

This region has undergone intensive deforestation over the past centuries, and currently hosts only $10 \%$ of its original forest cover (Saatchi et al, 2001, Costa et al 2005). Viana et al. (1997) calculate an even more serious degree of alteration, with less than $5 \%$ of the original Atlantic Coastal Forest remaining in that region.

Some cocoa (Theobroma cacao) plantations follow an agro-forest model that involves only the thinning of the lower canopy and planting in the understory, while maintaining the original upper canopy vegetation. This system is locally known as “cacau-cabruca”. As this crop is planted mostly on the hillsides and near water courses (to facilitate drainage), numerous hill top "forest-islands" now compose the forest mosaic of the region, in addition to the relatively intact and continuous upper canopy(May e Rocha, 1996, Sambuichi, 2006).

Due to the peculiarities of the cocoa region in southern Bahia State (especially its unique agricultural system and its high biodiversity - Cassano et al, 2009), numerous "in situ" conservation strategies are being tried, with the principal goal of diminishing deforestation rate.

While developing the zoning plan for the Biosphere Reserve of the Atlantic Coastal Forest - RBMA, state and federal conservation areas already established within the cocoa region of southern Bahia were classified as "core zones" for resource conservation because of their high biodiversity. Within Biosphere Reserve's "buffer zone" are cocoa plantations (the principal agricultural product in the region) and other agro-forest cultivars, such as 'piaçava' (Attalea funifera), 'pupunha' (Bactris gasipaes), and rubber (Hevea brasiliensis).

\subsection{Full Protection Areas and buffer zones within the Cocoa Region of southern Bahia}

The Una Biological Reserve (Rebio Una) was created in 1980 with the goal of preserving the last remnants of primary forest where groups of the endemic Goldenheaded Lion Tamarim (Leontopithecus chrysomelas) still existed. This primate is in the official list of Brazilian animals threatened with extinction, and there is an international force working to help assure its preservation. Environmental education programs for 
the preservation of this species are regularly held in the region, aiming to maintain the forested areas critical to their survival in and around the Una Biological Reserve (MALLINSON, 2001).

The high local diversity of the vegetation and the large number endemic species in the reserve were studied by Thomas et al. (1998). These researchers found 420 high vascular plant species within the reserve area, of which $45.2 \%$ were endemic to the Atlantic Coastal Forest.

The Una Biological Reserve has a buffer zone that was established before law $\mathrm{n}^{\circ}$ 9.985/00 came into effect (as its management plan was approved in 1998). As a result, the management policy for this zone had to be adjusted to the new legislation within 5 years of the new law taking effect. A number of projects were undertaken within the buffer zone along with the local property owners in an attempt to guarantee its success as a management strategy (see SANTOS and BLANES, 1997; and ORLANDO, 1997).

The public policies presented in IBAMA (1998) for the area surrounding the Una Biological Reserve puts the highest priority on the suppression of logging and illegal hunting, as well as the discontinuation of financing for projects that would involve intensive use of those lands, such as cattle raising and monoculture. One of the possibilities suggested was funding for the creation of private sustainable-use conservation areas.

The government of the state of Bahia created the "Serra do Conduru” State Park in 1997 (originally with 7000 hectares, but later increased to 9275 ha). This reserve was created in order to preserve the high species diversity of high vascular plants in the area (430 species) with their high degree of endemism (47.7\%) (see THOMAS et al., 1998).

\subsection{Sustainable Use Conservation Areas established in the Cocoa Region of southern Bahia State.}

According to Costa et al (2004), there are more than 450 RPPN within the Atlantic Coastal Forest, totaling altogether almost 100000 hectares. Most of these RPPN (65\%) are small, with less than 100 hectares. Slightly less that $10 \%$ are larger than 1000 hectares, while more than 25\% are between 100 and 500 hectares. These authors believe that in spite of their generally reduced size, RPPN have an important role in biodiversity conservation because of the connectivity they provide.
There are currently a little more than 60 RPPN in the state of Bahia, covering more than 12000 hectares. There are incentives being offered for the expansion of RPPN in the cocoa region through a Private Reserves Program. This program is being financed by "Conservação Internacional do Brasil” and "SOS Mata Atlântica”, under the coordination of a local NGO, together with an association of owners of private reserves in Bahia State. This program assists interested landowners during the process of reserve creation, and also aids in the construction of management plans for areas that have been effectively established. There are presently 16 RPPN in the cocoa region, with almost 2.500 hectares of land set aside.

For this work we also reviewed the process of creation of RPPN at IBAMA headquarters in Salvador, in order to identify: property size, percentage of area preserved, stage of vegetation succession - divided according to the Federal Decree No. 750 / 93 in (initial (I), mid (M) and final (F) stages of regeneration, PF - primary forest), interval between the beginning and end of the process (mouth), date of first land title, number of owners in history since the first land title; last rural paid land tax and annual tax value (U.S. \$) per hectare. After reviewing the cases were interviewed with the owners of RPPN to confirm this information.

\section{RESULTS AND DISCUSSION}

\subsubsection{Profiles of the Private Reserves in the Cocoa Region of southern Bahia}

We analyze the characteristics of the 14 RPPN created before 2005, according to the official IBAMA files for the cocoa region, witch are listed in Table 1.

The spatial configuration of these areas (Figure 1) reveals the existence of a number of gaps and a lack of connectivity between the different PA, but also shows that a significant number (57\%) of RPPN are located within the buffer zones of the Full Protection PA. This association between RPPN and buffer zones in the region is equal to that seen for all of Latin America (MESQUITA, 1999).

There are four RPPN located within the buffer zone of the Una Biological Reserve (covering a total area of 300 ha), and six RPPN within the buffer zone of the Serra do Conduru State Park (a total area of 1300 ha). The latter represent fully $50 \%$ of the area of all the $\mathrm{RPPN}$ in the entire cocoa region in southern Bahia.

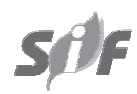

Revista Árvore, Viçosa-MG, v.34, n.4, p.699-711, 2010 
Table 1 - Areas, number and proportional relationship between RPPN areas and areas of their municipalities. Tabela 1 - Área, número e proporções entre as áreas das RPPNs e as áreas dos municípios.

\begin{tabular}{|c|c|c|c|c|}
\hline \multicolumn{2}{|c|}{ Municipality } & \multirow[t]{2}{*}{ Number of RPPN } & \multirow[t]{2}{*}{ Area of $\mathrm{RPPN}\left(\mathrm{Km}^{2)}\right.$} & \multirow[t]{2}{*}{$\%$ of Area preserved } \\
\hline$\overline{\text { Name }}$ & Total area $\left(\mathrm{km}^{2}\right)$ & & & \\
\hline Camacan & 632.93 & 01 & 8.00 & $1.26 \%$ \\
\hline Ibicaraí & 217.91 & 01 & 0.95 & $0.43 \%$ \\
\hline Ilhéus & 1840.99 & 04 & 1.66 & $0.09 \%$ \\
\hline Itacaré & 730.28 & 03 & 5.17 & $0.70 \%$ \\
\hline Jussari & 356.74 & 01 & 2.00 & $0.56 \%$ \\
\hline Una & 1159.53 & 02 & 1.22 & $0.11 \%$ \\
\hline Uruçuca & 337.71 & 02 & 0.307 & $0.09 \%$ \\
\hline
\end{tabular}

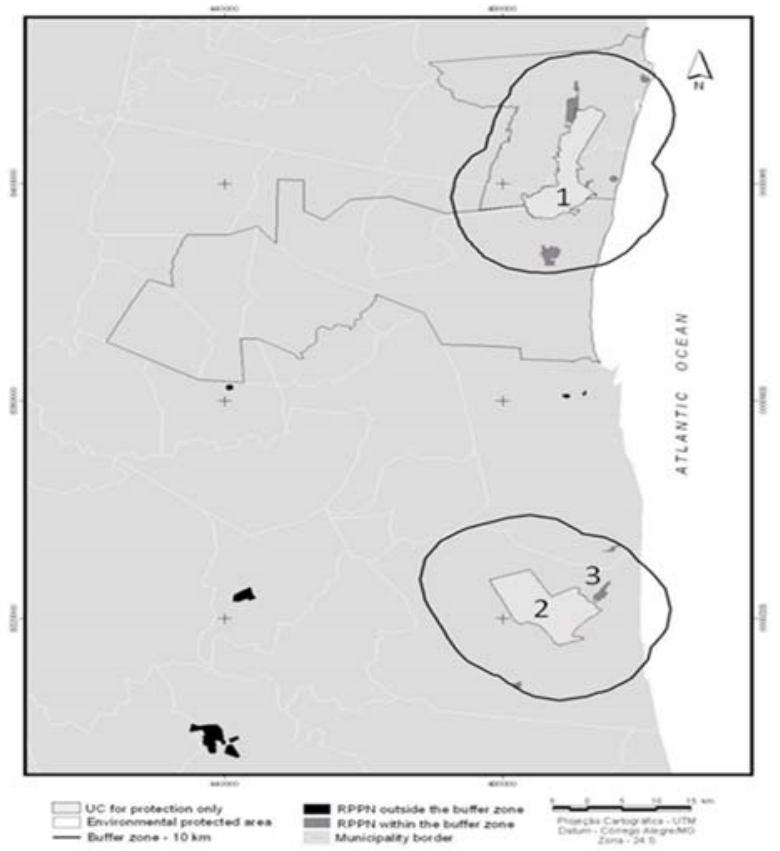

Figure 1 - Location of the RPPN and the PA within the cocoa region of southern Bahia State, Brazil: (1) Serra do Conduru State; (2) Una Biological Reserve; and (3) Ecoparque de Una RPPN.

Figura 1 - Localização das RPPN e das Áreas Protegidas na Região Cacaueira do Sul da Bahia, Brasil: (1) Parque Estadual Serra do Conduru; (2) Reserva Biológica de Una; e (3) RPPN Ecoparque de Uma.

There are currently two state Environmental Protection Areas (category V by IUCN) - APA (in Portuguese) within the cocoa region of southern Bahia - the APA “Costa de Itacaré - Serra Grande” (62 960 ha) and the APA “Lagoa Encantada e Rio Almada” (157 745 ha). This kind of PA has been created in Brazil to organize occupation and human activities in sensitive areas. Both states APA, however, are having difficulties functioning, principally due to the lack of knowledge on the part of the private landowners there concerning the planning and use norms established in the zoning and management policies of the APA. Of the total number of private reserves analyzed in this study, five are located within these two APA (within their restricted-use zones).

\subsubsection{Characterization of the Private Reserves}

The proportional area of private reserves is very small, and only one municipalities (Camacan) have slightly more than $1 \%$ of their land area transformed into RPPN.

The 14 RPPN analyzed in the cocoa region vary in size from 4.7 to 800 ha, and they are part of larger properties that range from 14 to 1200 ha. These RPPN are of modest size, with $50 \%$ of them being smaller than 50 ha. Twenty-four percent of the RPPN examined by Mesquita et al. (2000) in Latin America had areas smaller than 50 ha, while 19\% were larger than 2.500 ha (four times larger than the largest RPPN in the cocoa region) (Table 2 ).

The RPPN that have the largest areas in relation to their parent properties Ecoparque Una, Rio Capitão, Araçari, Serra Bonita, and Estância Manacá, and represent $100 \%, 82.9 \%, 73.3 \%, 66 \%$, and $59.7 \%$ of the total area, respectively. All of the landowners of these RPPN with high percentages of conversion to private reserves stated that these areas where in fact acquired with the intention of preserving the bulk of the land. This indicates a new focus for the rural land market: investments in rural areas for preservation purposes (agricultural income not being the most important consideration). This behavior points towards a new type of rural landlord, with a more conservationist, or at least preservationist, outlook. 
Of the RPPN studied, only one belonged to an environmental NGO (7\% of the total), significantly below the 25\% found for all of Latin America (MESQUITA et al., 2000).

In order to establish a RPPN, IBAMA must first evaluate the land. This official evaluation describes in detail the forest type and the regeneration stage of the Atlantic Coastal Forest (according to Federal Decree $\left.n^{\circ} 750 / 93\right)$. There are four RPPN in the cocoa region that contain primary forest (in the municipalities of Jussari, Una, and Camacan), but only one forest area is fully intact (see Table 2). The other three RPPN that contain primary forest also retain sections in initial (I), mid (M), and final (F) stages of regeneration.

All of the other ten RPPNs are covered by secondary forest, with sections either in advanced, mid, or initial stages of regeneration. These reports describe the presence of wild animals (some threatened with extinction) and valuable timber trees in all areas, except for a notation for the smallest reserve ( 4.7 ha.) indicating that no animals were observed there.

Seven of the fourteen RPPN either bordering or are fully contained within larger conservation areas, magnifying the importance of these Atlantic Coastal Forest fragments (MESQUITA and VIEIRA, 2004). As these RPPNs border or contained within other larger conservation areas, they reinforce the strategy of fostering nature corridors with the Atlantic Coastal Forest, and complement the nearby cacau-cabrucas.

\subsubsection{The creation order of the RPPN in the cocoa region and their ownership records}

The federal government instituted the concept of RPPN in 1990, but it was not until 1997 that the first private reserves were established in the cocoa region. This came about only after the NGO "Instituto de Estudos Socioambientais do Sul da Bahia (IESB)” started a program of incentives to create reserves on private lands (MESQUITA and LEOPOLDINO, 2002). In the first four years of this project (1997-2000) nine RPPN were established in the region. In the subsequent four years (2001-2005), however, there was a deceleration in the creation rates of RPPN, with only four new areas set aside.

This might have been be the result of a number of factors such as the expectation of renewed profits from the cocoa production (research is currently underway that may result in the development of hybrid plants that are resistant to the "witches-broom" fungus), but bureaucracy-related factors have also come into play. After the passing of the SNUC legislation, IBAMA increased mandatory paperwork to establish RPPN.

Table 2 - Some characteristics of the of Private Natural Heritage Reserves studied.

Tabela 2 - Características das Reservas Particulares do Patrimônio Natural estudadas.

\begin{tabular}{|c|c|c|c|c|c|c|c|c|c|c|}
\hline RPPN name & $\begin{array}{l}\text { Municipality } \\
\text { (ha) }\end{array}$ & $\begin{array}{l}\text { P. S. } \\
\text { size (ha) }\end{array}$ & RPPN & \% A. P. & F. T. & Interval & $1^{\text {st }}$ L.T. & $\begin{array}{l}\text { O. N. } \\
\text { (U\$) }\end{array}$ & R L.T. & $\begin{array}{l}\text { T.V } \\
\text { (U\$) }\end{array}$ \\
\hline Araçari & Itacaré & 150 & 110 & $73.3 \%$ & $\mathrm{M}$ & 17 & 1950 & 4 & 28.18 & 0.19 \\
\hline Araraúna & Una & 100 & 39 & $39 \%$ & $\mathrm{PF}, \mathrm{M}, \mathrm{F}$ & 14 & 1960 & 5 & 4.54 & 0.05 \\
\hline Arte Verde & Ilhéus & 25 & 10 & $40 \%$ & F & 23 & - & 2 & 11.36 & 0.45 \\
\hline Ecoparque Una & Una & 83 & 83 & $100 \%$ & $\mathrm{PF}, \mathrm{I}, \mathrm{M}$ & 13 & 1969 & 2 & 5.5 & 0.02 \\
\hline Estância Manacá & Ibicaraí & 159 & 95 & $59.7 \%$ & $\begin{array}{c}\text { excellent state } 21 \\
\text { of conserv.*** }\end{array}$ & 4 & 1950 & & 4.54 & 0.03 \\
\hline Jindiba & Uruçuca & 14 & 4,7 & $33.5 \%$ & M & 11 & 1989 & 2 & 8.52 & 0.61 \\
\hline Mãe da Mata & Ilhéus & 63.7 & 13 & $20.6 \%$ & $\mathrm{I}, \mathrm{M}, \mathrm{F}$ & - & - & 2 & 5.38 & 0.08 \\
\hline Paraíso & Uruçuca & 57 & 26 & $45.6 \%$ & M & 23 & 1992 & 2 & 4.54 & 0.07 \\
\hline Pedra do Sabiá & Itacaré & 117 & 22 & $18.8 \%$ & M, F & 14 & 1981 & 2 & 20.23 & 0.17 \\
\hline Rio Capitão & Itacaré & 464 & 385 & $82.9 \%$ & $\mathrm{I}, \mathrm{M}, \mathrm{F}$ & - & 1954 & 2 & 267.58 & 0.45 \\
\hline Salto Apepique & Ilhéus & 420 & 118 & $15.8 \%$ & F & 12 & 1950 & 1 & 407.52 & 0.52 \\
\hline São João & Ilhéus & 79 & 25 & $31.6 \%$ & $\mathrm{~F}$ & 05 & 1992 & 2 & 64.39 & 0.82 \\
\hline Serra Bonita & Camacan & 1200 & 800 & $66 \%$ & PF, I, M, F & - & 1971 & 35 & 11.14 & 0.01 \\
\hline Serra do Teimoso & Jussari & 520 & 200 & $38.4 \%$ & PF & 06 & 1906 & 1 & 252.72 & 0.49 \\
\hline
\end{tabular}

P.S. - property size (ha); \% A.P. - percentual of area preserved, F.T. - forest type (initial (I), mid (M), and final (F) stages of regeneration, PF - primary forest); between the beginning and end of the process (mouth); $1^{\text {st }}$ L.T. - date of $1^{\text {st }}$ land title; O. N. - owners in the history since $1^{\text {st }}$ land title; R.L.T. - Last rural land tax; T.V. - Annual Tax value (U\$) per hectare ** Report not classified according to Federal Decree 750/93

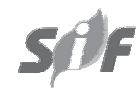

Revista Árvore, Viçosa-MG, v.34, n.4, p.699-711, 2010 
This created delays in both the processing of the requests and the approval of the reserves, and dampened the spirits and patience of those who might have had the initiative to create conservation areas. The bureaucratic processes involved in establishing the first three reserves created in the cocoa region were resolved relatively rapidly (see Table 2 ), but some later processes stalled for up to two years.

In February 2005, in an attempt to diminish the bureaucratic loggerheads, new instructions were issued by IBAMA. Among the changes made were the easing of the updating the title deed of the land and for the inclusion of geo-referenced information about the property boundaries (specifying geographic coordinates of the land). The owner was also declared exempt of the requirement to furnish a 50-year history of the land titles (if this information was not readily available in the local land office). However the owner had to demonstrate that this documentation had, in fact, been requested at the land office, and a current and legal deed for the property had to be presented. In addition to these bureaucratic requirements, there were no significant economic incentives for establishing these reserves. Exemption from the already low land taxes (see below) did not generate any economic motivation to transform forested areas into reserves.

An analysis of the documents submitted to create RPPN demonstrated that some of then did not have complete long-term land records. However, land titles for five areas go back at least 60 years, and four more reach back 40 years (Table 2 ).

Another important point is that there was little turnover of ownership in a majority of the reserves during the second part of the twenty century. In two areas (the Serra do Teimoso and Salto Apepique) the farms were owned by single families for ore than 90 and 50 years, respectively and the forests there were classified as primary and advanced-stage secondary (also respectively, see Table 2).

The RPPN of Pedra do Sabiá, Rio Capitão, Ecoparque Una, and São João had at the most two different families/ landowners. Wilson (1992) and Azevedo (2000) noted that the duration of ownership is the most important factor influencing a decision to preserve any land. This observation was confirmed in the present study.

In four other reserves, ownership histories described in the deeds are restricted to the previous owner. The RPPN of Estância Manacá is composed of four different properties, but there is only a deed registry for the first property (although this first property has been with the same family for more than 50 years). The other three properties were acquired in 1997 and the deeds bear only the name of the previous owner. According to documents of the IBAMA, the vegetation on this land is dense and in an excellent state of conservation.

The first registered deed emitted for the RPPN Araraúna is dated 1976, and it passed through the hands of five other owners before being declared a RPPN. Some of the owners held onto the land for only a few months. In spite of this high ownership turnover, the area still has sections covered by primary forest, as well as other sections in mid and final stages of succession.

The RPPN of Serra Bonita was formed by the fusion of a number of properties. This is the only reserve that has the complete 50-year deed history required according to the official regulations of IBAMA. Fifteen of then were acquired from the state. These were mostly marginal areas, such as hilltops, which were state property until 2002. As these were not used for agricultural purposes they remained generally intact, and were described by IBAMA as being primary forest.

The remaining properties that today compose the RPPN Serra Bonita had very complex deed-histories, due to the large turnover of past owners. Some owners held on to the land for only a few months, while others owned two or more areas. All told, the area that now makes up the Serra Bonita RPPN has had a total of 33 owners (not counting the state lands).

\subsubsection{Rural land taxes paid before the creation of the RPPN}

Until 1990, the areas of Atlantic Coastal Forest that retained their original forest cover were officially considered unproductive (Alger and Caldas, 1994) and were required to pay high land taxes for this. At the same time, these lands were subject to appropriation by the land reform agency (Instituto Nacional de Colonização e Reforma Agrária - INCRA) at an official rate.

The rural land tax (Art. 29 of the Código Tributário Nacional, see Harada, 1998) falls upon lands outside the urban areas and its value depends on the productivity of the land and its commercial value. 
Harada (1998) noted that the rural land tax had traditionally been used as one of the tools of land reform and agricultural policy, and in order to guarantee productivity. It was a form of progressive-regressive tax, in that there were progressive increases as the land area increased, but lower rates depending on the degree of use of the land and the degree of efficiency of that use.

To calculate the rural land tax, the proportion of utilized to un-utilized area was derived. If $100 \%$ of the land was being utilized, the tax rate was $0.15 \%$ of the basic property value (before improvements). If only half the lands were productive, the tax rate would be $3.3 \%$. This progressive taxation of unproductive lands stimulated deforestation.

In southern Bahia state this situation was complicated after 1989 by the cocoa crisis. Alarge number of rural workers suddenly became unemployed and joined land reform movements to invade rural properties, thus threatening the landowners. Alger and Caldas (1994) suggested that the federal land reform policy was a secondary, but very significant, cause of deforestation in the cocoa region during the 1990's. The primary catalyst was, of course, the cocoa crisis itself and the economic migration to cattle ranching and farming practices that did not preserve the original forest cover.

The IBAMA requires a copy of only the last rural land tax receipt in order to grant RPPN status, so it was not always possible to compare the tax values of all the RPPN for the same period. The rural land tax values are showed in Table 2 to verify if there were local rate differences.

In some municipalities, such as Ilhéus, a significant reduction can be seen in the land tax values paid from 1998 on. Overall, it was clear that each municipality instituted its own interpretation of the tax rates, independent of the quantity of productive area or intact forest.

\subsection{The Ecoparque de Una RPPN: a case study}

Based on a strategy of strengthening conservation actions in buffer zones surrounding Full Protection conservation areas, Conservation International (CI), together with the IESB, acquired (in 1996) an area of 83 ha just outside the borders of the Una Biological Reserve, and transformed it (in 1999) into a RPPN. The main goal for creating the RPPN were to provide free movement for the local fauna around the area of the Una Biological Reserve, promote tourism based on contact with natural areas, and to serve as a model area for development strategies for local landowners that still have forest fragments in their properties.

In order to offer a unique nature experience, a canopy walkway was built through the treetops, as well as other tourist infrastructure, such as trails, cabanas, and restrooms. In the first year (1998) the Ecoparque de Una RPPN drew 1200 visitors, which grew to 4,450 by 2001 (SCHIAVETTI et al., 2004).

A recent inventory of the Ecoparque de Una RPPN reported 33 species of mammals (of which 7 were endemic to the Atlantic Coastal Forest), 190 birds (32 endemic species), and 14 amphibians (1 endemic). Of the endemic mammals, two were primates that are listed on the Brazilian threatened species list: the Golden-Headed-Lion-Tamarin (Leontopithecus chrysomelas) and the Buffy-Headed Capuchin (Cebus xanthosternos).

Mesquita (1999) analyzed the effectiveness of the management of the Ecoparque de Una PRN and found it to be below satisfactory levels in terms of planning and management programs. This author considered it best in terms of legalization of the reserve itself and in furnishing biological information. The overall effectiveness of this reserve was classified as mediumsatisfactory, with an average score of $63.9 \%$. However this autor did not analyzed the social benefits transferred to the local population by the establishment of the reserve. This item could significantly alter the index results, because the objectives of a private reserve should be to serve as a development model for the region, altering the paradigm of land use by using the forest to sustain itself and the regional biodiversity, and should seek to involve local citizens in these processes. In spite, Lima et al (2005) founded that 60\% of PA in Minas Gerais State have poor management level, but in this case the authors included the social benefits transferred to the local population.

An analysis of the relationships between the Ecoparque de Una RPPN and its workers and the neighboring owners/managers of private farms was undertaken in 2001. Free and semi-structured interviews with these neighbors were used to determine up to what extent the reserve is fulfilling its role as a model for sustainable development, while at the same time adhering to one of the main premises of eco-tourism - involving the local population. 
One form of analysis of the social relationships with the reserve was to determine the conservation attitudes of neighboring farmers, defined as the disposition towards certain behavior under specific circumstances (HAGVAR, 1994). According to this author, there are three behavioral dispositions linked to conservation: utilitarian attitudes (characterized by the use of the resources); ecological attitudes (that justify conservation by way of the ecological processes extant in the area); and ethical attitudes (in which the intrinsic value of nature is the most relevant consideration). It must be kept in mind, however, that the responses of the owners/managers reflect only that given moment in time when the research was undertaken, for changes in the economic or social situations may result in rapid changes in attitudes towards environmental issues.

Alexander (2000) carried out interviews with the resident neighbors of the "Community Baboon" Sanctuary (Belize) classifying their conservation attitudes as either positive or negative. This author found that a large majority of the residents had positive attitudes towards the efforts to conserve Black Howler Monkeys (Alouatta nigra). Gillingham and Lee (1999), on the other hand, examined the conservation attitudes of the neighboring populations to the "Selous Game” Reserve in Tanzania, and found that although a majority of the population understood the necessity of protecting wildlife, the unequal distribution of the benefits from conservation efforts was perceived as a problem.

Monitoring conservation attitudes of neighboring populations of a conservation area and its buffer zone is very relevant for its management, and if they result negative, the administration must be willing to modify management policies accordingly.

First hand knowledge by the owners/managers of the neighboring farms of the goals and infrastructure of conservation reserves must certainly be the first step in any strategy that seeks to change the use patterns of the region lands. However, only two of the interviewees knew anything significant about the Ecoparque de Una.

One of the interviewed justified his lack of knowledge of the reserve by saying "they never asked me to visit them, but if you say to me let's go, I'll go; but I won't go otherwise, I'm like that". This demonstrates that large gaps in local knowledge about how the RPPN functions will affect the cultural responses of the local population.
This is especially important because the concept of RPPN is based (in part) on the objective of demonstrating that eco-tourism can be an alternative source of income. The community surrounding the Ecoparque de Una RPPN should be invited to visit the area and see how the reserve functions - as a model for the rational use of the natural resources in the region. Bridgewater (2002) has stated that one of the objectives of a Biosphere Reserve (of which both the Ecoparque de Una RPPN and the Una Biological Reserve are nuclear areas) is to preserve regional cultural elements, elements that must be taken into account when buffer zones are established.

This lack of information about the goals of the reserve, or how they could be attained, is supported by the views of the neighboring landowners about conservation areas. Seven owners were only aware of the "utilitarian" nature of a forest reserve - an area that to them would provide bush-meat, water, wood for use on the property, and 'piaçava' (Attalea funifera) fiber (the only forest product of commercial value).

Only one owner/manager had what might be considered an "ecological” view. This singular view may be due to the property's economic independence from the use of forest products or from the low income of cocoa cultivation, as the principal economic activity on the farm is raising ostriches and buffalos for sale to large distributors.

Serious programs directed towards environmental education will be needed in order to change local attitudes towards conservation (see Carrillo \& Batista, 2007)

The fact that three owners/managers had attitudes classified as "ethical" must be considered a positive gain for the strategy of transforming these areas into private reserves and increasing protected areas at the border of the Una Biological Reserve. Any attempts to create a RPPN in these areas as part of the IESB program should result in positive gains for this conservation strategy.

Another route to establishing positive relationships between the owners/managers of neighboring properties and the philosophy of the RPPN would be by allowing them to participate in the economic benefits of the ecotourism being developed in the region, through the consumption of locally produced goods at the Ecoparque de Una RPPN. This partnership, however, has not yet been established, and there appears to be a real need for an emergency strategy by the reserve administration to promote local sustainability. 
This study also revealed that all of the properties along the boundaries of the Ecoparque de Una RPPN had larger forest reserve areas than were required by law. These extra areas could conceivably be transformed into RPPN, for although they are used for wood gathering, hunting, water resources, or for piaçava (Attalea funifera) fibers, they are not otherwise under a direct-use regime.

The analysis of the results of this survey indicate that although located adjacent to a Full Protection Area (the Una Biological Reserve), the Ecoparque de Una RPPN is not living up to its full potential as a buffer zone component.

\subsection{Recommendations for the management of the buffer zones of Full Protection Areas (FPA) in the cocoa region}

In spite of the numerous national and international conservation strategies and environmental policies focused on the region, the present situation of the cocoa zone is threatening the conservation of the region's natural resources

The overlapping international titles and programs (Biosphere Reserve and World Heritage Site) have not halted forest loss in the Atlantic Coastal Forest region. Costa et al. (2005) reported a 74.8\% deforestation rate in the Una region during the period 1985 to 1998. This apparent lack of success could be due in part to the reduced scale of the conservation areas within this large and heterogeneous biome.

The establishment of private reserves in the cocoa region could conceivably improve these conservation efforts. This type of reserve can be established under a uniform system supported by federal legislation, and could count on private organizations such as CI and the IESB for technical help and support for projects related to their establishment and management. As these areas tend to be small, they can be set up and managed relatively quickly and inexpensively, thus increasing their likelihood of becoming effective and functional conservation areas.

RPPN should be established to help conserve the biodiversity in buffer zones as part of an overall strategy for Brazilian conservation areas, with the goal of maximizing the probability of maintaining viable forest fragments. These benefits would be especially noticeable in the cocoa region. The Una Biological Reserve and the Serra do Conduru State Park are the largest forested regions in the region, and the creation of private reserves along their boundaries is the most viable strategy for creating biological corridors to help conserve the endemic regional flora and fauna.

However, for this strategy to be truly effective local populations must be consulted, economically involved with planning and development processes, and must have an active participation in the activities developed within the reserve, while at the same time their traditional cultural values must be respected.

\section{ACKNOWLEDGEMENTS}

The authors would like to thank the Instituto de Estudos Sócio-ambientais do Sul da Bahia (IESB) and the Universidade Estadual de Santa Cruz (UESC) for the information they provided as well as the logistic and financial support for this work, Dr ${ }^{\mathrm{a}}$ Maria Eugênia Bruck de Moraes, Gecely Alves Rocha and Romari A. M. Montano for their critical reading of this paper.

\section{REFERENCES}

ALEXANDER, S.E. Resident attitudes towards conservation and black howler monkeys in Belize: the Community Baboon Sanctuary.

Environmental Conservation, v. 27, n. 4, p. $341-350,2000$.

ALDERMAN, C.L. The economics and the role of privately-owned lands used for nature tourism, education and conservation. In: Munasinghe, M.; McNeely, J. (Eds)

Protected areas, economic and policy: linking conservation and sustainable development. World Bank/ IUCN, p. 273-317, 1994.

ALGER, K AND CALDAS, M. The declining cocoa economy and the Atlantic forest of Southern Bahia, Brazil: conservation attitudes of cocoa planters. The Environmentalist, v. 14, n. 2, p. 107-119, 1994.

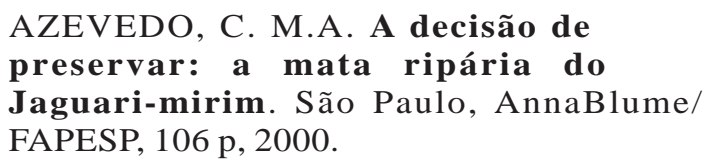

BRIDGEWATER, P.B. Biosphere reserves: special places for people and nature. Environmental Science and Police, v.5, p. 9 -12, 2002.

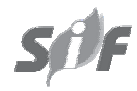

Revista Árvore, Viçosa-MG, v.34, n.4, p.699-711, 2010 
CAPOBIANCO, J.P.R. Situação atual e perspectivas para a conservação da Mata Atlântica. In: Lima, A. (Ed) Aspectos jurídicos da proteção da Mata Atlântica. Documentos ISA, v. 7, São Paulo, p. 9 - 16, 2001.

CARRIILLO, A.C. AND BATISTA, D.B. A conservação do papagaio-da-cara-roxa (Amazono brasiliensis) no Estado do Paraná - uma experiência de educação ambiental no ensino formal. Revista Árvore, Viçosa - MG, v.31, n.1 p, 113-122, 2007.

CASSANO, C.R. SCHROTH, G.; FARIA, D.M.; DELABIE, J.H.C. AND BEDE, L. Landscape and farm scale management to enhance biodiversity conservation in the cocoa producing region of southern Bahia, Brazil. Biodiversity and Conservation, v. 18, n 3, march, 2009.

COSTA, C.M.R.; HIROTA, M.M.; PINTO, L.P.; FONSECA, M.T.; LAMAS, I.R.; BRITO, M.C.W. AND MESQUITA, C.A.B. Incentivo à criação e gestão de Reservas Particulares do Patrimônio Natural (RPPN): uma estratégia para a conservação da Mata Atlântica. In: Castro, R. and Borges, M.E. (Org) RPPN - Conservação em Terras Privadas: desafios para a sustentabilidade. Planaltina do Paraná, CNRPPN: p. 95 - 105. 2004.

COSTA, K. L.; SILVA JUNIOR, M.C. AND VALLADARES-PÁDUA, C. Dynamics of the Mata Atlantic's (Atlantic Rainforest) forest coverage at the Una (Bahia State): 1985-1998. Natureza and Conservação, v. 3, n. 1, p. 171-186, 2005.

DA FONSECA, G.A.B. The vanishing Brazilian Atlantic Forest. Biological Conservation, v. 34, p. $17-54,1985$.

GILLINGHAM, S. AND LEE, P.C. The impact of wildlife-related benefits on the conservation attitudes of local people around the Selous Game Reserve, Tanzania. Environmental Conservation, v. 26, n.3, p. $218-228,1999$.

HAGVAR, S. Preserving the natural heritage: the process of developing attitudes. Ambio, v. 23, n. 8, dec, p. $515-518,1994$.

HANNAH, L.; LOHSE, D.; HUTCHINSON, C.; CARR, J.L. AND LANKERANI, A. A preliminary inventory of human disturbance of world ecosystems. Ambio, v. 23, n. 4-5, july, p. 246-250, 1994.

HARADA, K. Direito financeiro e

tributário. São Paulo, Atlas, 4ª ed., 447 p. 1998.
INSTITUTO BRASILEIRO DE MEIO AMBIENTE, Programa de Reserva Particular do Patrimônio Natural, RPPN: Uma inovação no contexto da conservação brasileira. Brasília, DF: Diretoria de Ecossistemas, IBAMA, 27 p. 1997.

INSTITUTO BRASILEIRO DE MEIO AMBIENTE. Plano de Manejo da Reserva Biológica de Una. Brasília, DF: Diretoria de Ecossistemas, IBAMA, 286 p, 1998.

LANGHOLZ, J. Parques de propriedade privada. In: Terborgh, J.; Schaik, C. Davenport, L. and Rao, M. (Org) Tornando os Parques eficientes - estratégias para a conservação da natureza nos trópicos. Curitiba, Fundação O Boticário: p. 197 - 212, 2002.

LI, W.; WANG, Z. AND TANG, H. Designing the buffer zone of a nature reserve: a case study in Yancheng Biosphere Reserve, China. Biological Conservation, v. 90, P. 159-165, 1999.

LIMA, G.S, RIBEIRO, G.A. and GONÇALVES, W. Avaliação da efetividade de manejo das Unidades de Conservação de Proteção Integral em Minas Gerais. R. Árvore, Viçosa, MG, v. 24, n. 4, p. 647-653, 2005.

MALLINSON, J. Salving Brazil's Atlantic Forest: using the Golden-headed lion tamarim Leontopithecus crysomelas as a flagship for a biodiversity hotspot. Dodo, v. 37, p. 9 -20, 2001.

MAY, P.H. AND ROCHA, R.B. O sistema agrosilvicultural do cacau-cabruca. In: Lopes, I.V.; Bastos Filho, G.S.; Biller, D. and Bale, M. (Org) Gestão ambiental no Brasil: experiências e sucessos. Fundação Getúlio Vargas, $1^{\text {a }}$ ed.: p. 35 - 62, 1996.

MESQUITA, C.A. Caracterizacíon de las reservas privadas em América Latina. Magister Scientiae Tesis, Turrialba, Costa Rica. 88 pp, 1999.

MESQUITA, C.A., AGUIRRE, J.A., CIFUENTES, M. AND MÜLLER, E. Caracterización de las reservas naturales privadas en América Latina. Revista Forestal Centroamericana, v. 30, abril-junio, p. 51-57, 2000.

MESQUITA, C.A.B.. LEOPOLDINO, F. Incentivando e apoiando a criação, manejo e integração de Reservas Particulares do Patrimônio Natural (RPPN). Proceedings... Fortaleza, Congresso sobre Unidades de Conservação, III,: p. 798-794, 2002. 
MESQUITA, C.A.B. AND VIEIRA, M.C.W. Reservas Particulares do Patrimônio Natural da Mata Atlântica. São Paulo, Conselho da Reserva da Biosfera da Mata Atlântica, 56 p. 2004.

MITTERMEIER, R.A.; MYERS, N.; THONSON, J.B.; FONSECA, G. AND OLIVIERI, S. Biodiversity hotspot and major wilderness areas: approaches to setting conservation priorities. Conservation Biology, v. 12, p. 516 - 520, 1998.

MYERS, N.; MITTERMEIER, R.; MITTERMEIER, C.; FONSECA, G. AND KENT, J. Biodiversity hotspot for conservation priorities. Nature, v. 403, n. 24, p. 853-858, 2000.

ORLANDO, H. Unidades de conservação e manejo da zona de entorno. In: Proceedings..., Curitiba, Congresso Brasileiro de Unidades de Conservação, 1, IAP/UNILIVRE: p. 764 - 775, 1997.

PINTO, L. P. S. Geographic distribution of the Golden-headed lion tamarin, Leontopithecus crysomelas, implications for its management and conservation. Folia Primatologica, v. 68, n. $161-180,1997$.

SAATCHI, S.; AGOSTI, D.; ALGER, K.; DELABIE, J. \& MUSINSKY, J. Examining fragmentation and loss of primary forest in the Southern Bahian Atlantic Forest of Brazil with radar imagery. Conservation Biology, v. 15, n. 4, p. 867-875, 2001.

SAMBUICHI , R. H. R. Estrutura e dinâmica do componente arbóreo em área de cabruca na região cacaueira do sul da Bahia, Brasil. Acta Bot. Bras., v.20, n.4, São Paulo Oct./ Dec, 2006.
SANTOS, G.J. R, BLANES, J. Environmental education programme: with the community surrounding Una Biological Reserve, Bahia, Brazil. Dodo J. Wild. Preserv. Trust, v. 33, p. 118 - 126, 1997.

SILVA, M. The Brazilian Protected Areas program. Conservation Biology, v. 19, n. 3, $608-611,2005$.

SCHIAVETTI, A.; OLIVEIRA, H. T.; SCHILLING, A. C.; NORDI, N. Dinâmica turística de la reserva particular del patrimonio natural Ecoparque de Una (Region Cacaueira - Sur del Bahia - Brasil). Estudios Y Perspectivas En Turismo, Argentina, v. 13, n. 3, p. 36-58, 2004.

THOMAS, W.W., CARVALHO, A. M.V., AMORIN, A.M.A., GARRISON, J. AND ARBELÁEZ, A. L. Plant endemism in two forests in Southern Bahia, Brazil. Biodiversity and Conservation, v. 7, p. $311-322,1998$.

VIANA, V. M.; TABANEZ, A.A.J. AND BATISTA, J.L.F. Dynamics and restoration of forests fragments in the Brazilian Atlantic moist forest. In: W.F. Laurence and R.O. Bierregaard Jr. (Eds) Tropical forest remnants: ecology, management and conservation of fragments communities. The University of Chicago Press, Chicago, p. 351 - 365. 1997.

WELLS, M., BRANDON, K. The principles and practice of buffer zones and local participation in biodiversity conservation. Ambio, v. 22, n. 2-3, may, p. 157 -162, 1993.

WILSON, G. A survey on attitudes of landowners to native forest on Farmland (New Zeland). J. Env. Management, v. 34, p. 117-136, 1992. 